WellBeing International

WBI Studies Repository

1991

\title{
Animals in Biomedical Research: The Undermining Effect of the Rhetoric of the Besieged
}

John P. Gluck

University of New Mexico

Steven R. Kubacki

University of New Mexico

Follow this and additional works at: https://www.wellbeingintlstudiesrepository.org/acwp_arte

Part of the Animal Experimentation and Research Commons, Animal Studies Commons, and the Bioethics and Medical Ethics Commons

\section{Recommended Citation}

Gluck, J. P., \& Kubacki, S. R. (1991). Animals in biomedical research: The undermining effect of the rhetoric of the besieged. Ethics \& behavior, 1(3), 157-173.

This material is brought to you for free and open access by WellBeing International. It has been accepted for inclusion by an authorized administrator of the WBI Studies Repository. For more information, please contact wbisr-info@wellbeingintl.org.

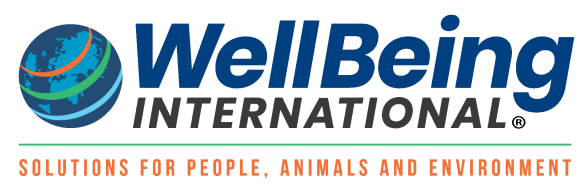




\title{
Animals in Biomedical Research: The Undermining Effect of the Rhetoric of the Besieged
}

John P. Gluck and Steven R. Kubacki

University of New Mexico

\begin{abstract}
$\underline{\text { ABSTRACT }}$
It is correctly asserted that the intensity of the current debate over the use of animals in biomedical research is unprecedented. The extent of expressed animosity and distrust has stunned many researchers. In response, researchers have tended to take a strategic defensive posture, which involves the assertation of several abstract positions that serve to obstruct resolution of the debate. Those abstractions include the notions that the animal protection movement is trivial and purely anti-intellectual in scope, that all science is good (and some especially so), and the belief that an ethical consensus can never really be reached between the parties.
\end{abstract}

It is widely held that the current debate on the use of animals in research is unprecedented with respect to its intensity and to the extent that it has captured the public consciousness (Dewsbury, 1990). The debate is elaborated regularly in newspaper articles, editorials, personal help columns (e.g., "Dear Abby"), news magazine cover stories, television specials, and prestigious professional journals in a variety of specialties. It has also been stated by Dr. Charles McCarthy, Director of the Office of Protection from Research Risks, that Congress has received more mail on this issue than any other topic in the entire history of the country (C. R. McCarthy, personal communication, January 15, 1988). Although many authors (e.g., Feeney, 1987) have drawn attention to the similarities between the current debate and the vivisection arguments of the past century, these comparisons fail to capture the broader issue base of the present concerns. Additional questions relating to the use of and treatment of animals in product testing, clothing, sport hunting, entertainment, and intensive agriculture have been raised and related to the general topic of environmental relationships and the meaning and importance of the human-animal bond (Dewsbury, 1990; Katcher \& Beck, 1983; Lawrence, 1982).

In their pathfinding book, Metaphors We Live By, Lakoff and Johnson (1980) discussed how the metaphor "argumentation is war" permeates the way in which modern Western culture discusses and resolves its conflicts. When Westerners talk about the way they argue, they employ a bellicose vocabulary. There are winners and losers, defenses and offenses, and strategies and counterstrategies. Often, the purpose of 
discussion is not further understanding and cooperation, but victory and domination by one side or the other; compromises are temporary truces, not signs of a deepening understanding; the ultimate goal of triumph by one side or the other is never doubted.

Unfortunately, and true to our cultural heritage, such a state of siege exists among the various factions of the animal protection movement and animal researchers. Members of both general positions describe the current situation in the vocabulary of war. For example, Karl J. Hittelman (1989), a chancellor of academic affairs at the University of California, closed his address at a recent animal care and use conference by asking the scientists who were present to "join us at the barricades." This state of war has resulted in the hardening of abstractions, with each side calling the other anti-intellectual, sadistic, and uncaring while describing themselves in terms that attest to purity of mind and intention and identifying themselves as those truly concerned with suffering. The Animal Liberation Front, an activist animal protection group, parades pictures of masked individuals who have broken into laboratories on rescue missions; the Foundation for Biomedical Research runs advertisements implying that members of the animal protection community do not care about people with cancer, heart disease, and AIDS and asks, "Who will stop the real killers?" Although researchers are often pictured as sadistic fools in the public press of the protection movement (e.g., The Animals' Voice, The Animal Agenda), researchers give the impression that a human baby is saved with each sacrificed rat, dog, and monkey. The National Association for Biomedical Research and its sister organization, the Foundation for Biomedical Research, which are essentially proanimal research lobbying groups, recently requested that researchers submit material to them so that they could create a "family album" (see Trull, 1989) to show President and Mrs. Bush. The goal of the album was to provide material demonstrating that researchers "are people who care about their families, who have pets, and who believe that through research we can ensure [italics added] a better life for people and animals." The memo also encourages people to "if possible, include a letter from your child." The situation brings to mind the statement by the British writer J.R. Ackerly, who, after beginning to read the Bible, wrote the following to a friend: "I am half way through Genesis and am quite appalled by the disgraceful behavior of all the characters, including God."

\section{COURSE TO THE DEVELOPMENT OF CONSENSUS}

Instead of the metaphor "argumentation is war," should our discussions regarding animal research not be governed by the metaphor "argumentation is concensus"? In such a metaphor, both sides would be motivated toward a rapprochement and a deepening understanding of the other's side. At the very least, such a metaphor would bring some measure of civility and compassion to the debate. As it stands now, there is just distrust, suspicion, and at times hatred.

In his Theory of Communicative Action, Habermas $(1984,1987)$ presented a profound theory of what it means to communicate. He distinguished between two types of human activity or action: instrumental action (IA), which is control and success oriented, and communicative action (CA), which is understanding oriented. Both orientations involve different knowledge interests or goals. In CA, speakers strive to reach an understanding of each other's positions in order to attain an acceptable consensus. Participants enjoy the freedom to either consent or dissent without fear of threat; that is, they are free to express what they truly think or feel. In contrast, the goal of IA is to achieve success or control. IAs are appropriate when problems to be solved are of a technical or objective nature, as in building a bridge. All human actions constitute a mixture of $C A$ and IA. When IA is guided by CA, both forms of actions can function harmoniously. However, when IA dominates CA, we have what Habermas called strategic action (SA).

In SA, the values of control and success dominate or eclipse the values of understanding. Therefore, in SA, participants focus on achieving a goal and use any available resources they deem necessary. They may be open about their intentions (e.g., "your money or your life") or covertly manipulative (e.g., "I want 
you to respect me so I'm only going to show you only my good side"). The effect is somewhat the same in either case. Namely, the participants are dehumanized.

It is our position that the intransigence of this debate is not likely to shift until all sides begin to move from their strategic positions to CA. Such a shift requires a reapportionment of attention. Currently, the biomedical research community is focused almost exclusively on the behavior of the protection movement. Defenses and counterattacks are planned that leave little time for critical self-examination and attempts to deepen awareness and understanding of the animal protection perspective. For example, Landers $(1989$, p. 1) quoted Charles Shuster, director of the National Institute of Drug Abuse in a news article entitled "Scientists Take Stand for Animal Research": "If someone tells me a monkey, or a dog or a rat is as important as my daughter, I'd part company with them." Shuster's advice is to part company, not look or discuss further, that is, to part company and not wonder about how differences could be so strong. Part company is a way of saying "I'm finished with you." In short, it is the language of war and not consensus.

What is required if this state of siege is to abate? First, each side must cease launching stereotyped, distorted, and vainglorious images of themselves at the perceived enemy and the undecided public. These are nothing but naked attempts to overpower and manipulate. Second, we must try to listen for the elements of truth nested in the attacks and assertions of our antagonists. In other words, a shift from SA to CA is required. Therefore, what follows is a discussion of three topics that, as a biomedical researcher, I believe have become working assumptions and that in turn have become hardened abstractions and as such now serve as obstacles to a deepened understanding. As Kierkegaard (1962, p. 9) wrote in The Present Age, the process of abstraction "transforms the real task into an unreal trick, and reality into a play."

The three assumptions are: (a) although the animal protection movement may be threatening and powerful, it is trivial; (b) all science is excellent and some is especially so; and (c) an ethical consensus cannot be reached. This article is not an exercise in the negation of the value of animal research. However, just as I believe that the animal protection movement has spread the tar too thickly on the entirety of animal research, we as researchers must be careful not to overlay all animal research with glory and to view the concerns of the animal protection movement as meritless interruptions. This article is also an invitation to supporters of the animal protection movement to examine their own obstacles to consensus.

\section{THE TRIVIALITY OF THE ANIMAL PROTECTION MOVEMENT}

The assertions here are that the concerns of the animal protection movement are a cyclical phenomenon (last confronted as the antivivisectionist movement of the 19th century) and that the cycle is driven by a basically anti-intellectual fervor. Feeney (1987, p. 593) put it simply, "There are always some groups that want to limit the inquiry of the human mind." Even if we accept this notion, it provides us no help because the questions, "Why the cycle?" and "Why the desire to limit this particular inquiry?" remain. Are we to assume that this cycle does not require or deserve our attention? Are we to consider this cycle of limitation a mere curiosity devoid of import comparable to our shifting preference for restaurants?

There are strong reasons to believe that the moral struggles about the place of animals and their treatment by humans may have a much longer history than we have typically allowed. Anthropologists and historians have drawn our attention to a range of ancient and relatively modem phenomena relevant to these questions, several of which I present here. 
The cave art from the upperpaleolithic period in southwestern Europe is one case. In the area of northern Spain and southern France, clustered around the Bay of Biscay, are found approximately 200 archeological sites that reveal rich and varied examples of this surprising artwork. These works of art were produced during the last ice age and date back from as long ago as 30,000 years. The creations-which include ivory and stone carvings, simple and polychrome paintings, and engravings--are almost exclusively renderings of common ice-age animals, some now extinct (e.g., bison, horse, deer, mammoths, and wild bulls). They are found in the recesses of the caves, not in the heavily used living areas. Some of the art appears to have been created at some risk to the artist in that it would have required ropes and scaffolds to reach the desired areas (Ruspoli, 1986). Many of the paintings are three dimensional due to the utilization of the natural contours of the stone surfaces to emphasize body shapes. The animal subjects of these paintings were ones both economically and noneconomically relevant. In other words, these artists painted animals that served as sources of food and fiber and made their survival possible as well those they simply encountered in their world. Given this context, the sensitivity of these paintings is even more dramatic. While viewing the paintings in the "Hall of the Bisons" in the cave of Altamira in the province of Santander, Spain, and using an indirect kind of flickering fire light, one experiences the images of the bisons as vibrant, alive, and moving. The paintings imply at least the existence of a sense of respect for animal life by these people if not the expression of a godlike sense of animal superiority or undifferentiated brotherhood (Berman, 1989). Perhaps this art is a respectful acknowledgment or atonement of the stark and difficult existential fact that life lives on life (Becker, 1973).

\section{The Ritual Apology}

There is more clear evidence that a difficult moral struggle exists in those people deeply dependent on animals for their survival. Tuan (1989) called our attention to the ancient rituals of apology offered to the prey of the Eskimo tribes. For example, the Netsilik Eskimos believe that to place a freshly killed seal on a dirty floor is an act of disrespect. They also believe that it is important to quench the dead animal's thirst before it is processed for food. Therefore, the hunter trickles a small amount of water into the mouth of the seal before beginning the butchering. These are seen as acts of respect and propitiation and are ways to ease the conscience of a people who, in order to live themselves, have to take so many animal lives. In North America, the Abnaki bear hunters declare to a slain animal, "Cousin, I have killed you because I need your skin for my coat and your flesh for my food. I have nothing else to live on!" In a similar fashion, the Ottawa plead with the spirit of the bear "not to leave with an evil thought against us because we have killed you. You have intelligence and can see that our children are starving. They love you. They want you to enter their bodies" (Hallowell, 1926, pp. 54-61). The Gilyak of east Siberia treat a slain bear as a special guest at a great feast by serving the bear a ritual meal of its own flesh (Campbell, 1983).

An interesting contrast to these practices of respect is the behavior of the Mbuti Pygmies of the African equatorial forest. These hunter-gatherers live in a lush and accommodating environment, which has led to the development of a rather relaxed, cooperative, and egalitarian life style. Getting enough to eat is a rather simple task that leaves the adults a good deal of free time to sing, dance, and play with the children. Their lives are characterized by a pronounced "exuberance and joy of living" (Turnbull, 1963, p. 11). Their treatment of animals, which make up only a small part of their diet, is unsentimental if not cruel. Turnbull (1962) reported hunting episodes where the distress of speared and dying animals is mocked and denigrated. It is also pointed out that, although the hunting behavior of the Mbuti seems guilt free, their mythologies emphasize the necessity for a respect of animal life. Certain popular stories capture and express the idea that treating animals as mere animals or casual unnecessary killing will result in the death of the tribe (Turnbull, 1962). Such a legend is presented here. 
A small boy, alone in the forest, heard such a beautiful song that he went to see who was singing and, discovering a bird-the bird of the most beautiful song in the forest-he brought it back to the camp to be fed. His father was annoyed to have to give food to a mere bird; but, the boy pleading, the bird was fed. Next day the song was heard again, and the boy again returned with it to the camp. The father was more annoyed than before, but again the bird was fed. Then a third day, and again the song! This time, taking the bird from his son, the father told him to run along; and when the boy was gone, the man killed the bird, and with the bird he killed the song, and with the song, himself. He dropped dead, completely dead, and was dead forever. (Turnbull, 1962, p. 83)

Pets

The widespread habit of pet ownership provides additional evidence that attests to the fact that our relationships with animals are riddled with emotional ambivalence and struggle. In the United States alone, pet ownership in the 1980s has been estimated to include approximately 500 million animals (Beck, 1983). The financial expenditures generated from this practice, including food and medical care, approach $\$ 8$ billion annually, with similar figures seen in Britain (Serpell, 1986). We dote on our pets personally and in official acts of public praise. For example, the "Dog Hero Awards" presented yearly by the KEN-L RATION company describes the carefully validated exploits of dogs and are similar in form and content to Congressional Medal of Honor citations.

Although it has been somewhat slow to develop, mental health specialists are now beginning to recognize that the grief reactions of pet owners can be serious situations requiring careful and sophisticated clinical interventions (Harris, 1983). On the other hand, pets are also the objects of almost unbelievable levels of human irresponsibility and neglect. Millions of pets are tossed away like just so much styrofoam trash. Estimates based on surveys indicate that at least one third of the dogs in the United States dies in animal shelters (Serpell, 1986).

It is absolutely clear that the pet phenomenon cannot be written of as an aberration of wealthy and overstuffed Western cultures. Serpell (1986) and Tuan (1984) did excellent jobs summarizing the cultural data on pet ownership. It is obvious from these accounts that the practice is widespread in a variety of tribal societies from the South Pacific to the Amerindian cultures. Similar to observations in the urban West, pets have high status and are cared for in ways that mirror the treatment of human children. To me, it is important to note that to continue to interpret pet keeping as a neurotic expression of overly sentimental and isolated human beings is to miss a major lesson about the power and importance of the pet-owner relationship.

\section{Statutory Regulation}

The formal expression of the concern for animal treatment in the West can be traced to the early 19th century. Movements on the continent and in England emphasized both general humane issues as well as antivivisectionist sentiments. Midgely (1983) stated that the first antivivisectionist society was initiated by the wife and daughter of the "father" of physiology, Claude Bernard, following the discovery that he had dissected the family's pet dog. The Cruelty to Animals Act became law in England in 1876. The law required experimenters to be licensed and their research facilities to be inspected. The law also limited the use of animals for the purpose of education. In America, the states of New York, Massachusetts, Connecticut, and Wisconsin were the first to pass anticruelty legislation that was patterned after the English model. The federal Animal Welfare Act was passed in 1966 after a furious episode of exposes of the practices of animal dealers and exhibitors. The act has been modified several times in the ensuing years, each change creating more stringent requirements. Unfortunately, these legislative initiatives are 
frequently reacted to as yet another form of anti-intellectual obstructionism instead of the expression of guilt and ambivalence more easily recognized in hunter-gatherer cultures. This guilt was sometimes symbolically transformed into beliefs about the reincarnation of humans into animals and animals into humans.

Perhaps this last point can be drawn into better focus if we consider the fact that an early prototype of the Animal Welfare Act was published as a series of carved inscriptions on rocks and pillars scattered throughout India. The author of these edicts was Emperor Asoka, who ascended to the throne in approximately $274 \mathrm{BC}$ and reigned for more than 40 years. Several of the edicts explicitly prescribed humane treatment of animals used for agriculture and entertainment purposes. For example, certain procedures for castration and branding were either outlawed or limited, animal fighting was prohibited, and hunting was restricted. Incredibly, the Emperor also set up a medical welfare system that was to treat the ills of both man and animals. Later in his reign, he mandated a series of empire-wide roadside rest areas to be constructed to comfort both human and animal travelers (Mookerji, 1928).

In summary, the animal protection movement is not a trivial, sentimental artifact of overly sensitive human beings with too much free time (Mittelman, 1989). This movement cannot be characterized and dispensed with by a simplistic anti-intellectual or antiscience tag. The historical and anthropological data point unmistakedly to the conclusion that the concern for animal life is a complex utterance that flows in part from a deep relational and existential recognition that life is life and that life lives on life. Given this context, we should expect the voice of the concerned to be at times anguished and shrill.

\section{ALL SCIENCE IS EXCELLENT AND SOME IS ESPECIALLY SO}

Just as the attacks on animal research have been very broad based, the defense has been equally general and at times distorted. As biomedical researchers, we have tended to identify ourselves and our work with the finest exemplars of animal research. This is natural enough and can be seen as an attempt to self-motivate to a higher level of professional performance. But when it is made to appear that these examples are typical of the quality and usefulness of animal research, we have entered the domain of strict strategic action. Worst of all, this dogma may become something that we ourselves begin to believe, furthering an arrogant and hardened stance, making one unwilling to listen and to search for consensus. The point is that there is ample evidence in the published literature about the dark side of research to chasten even the most committed researcher. The evidence is clear that all is not as well as we wish or as we represent it to the public.

\section{The Ortega Hypothesis}

Although it is well known that American winners of the Nobel prize come from a very small number of institutions, the Ortega hypothesis (named after Ortega Y. Gassett) expresses the widely held belief that all scientists contribute to discovery and scientific advances in their own unique and important way. In other words, major discoveries made by major scientists rest on a foundation of smaller discoveries made by scientists of more average ability. It follows then that the greater the number of scientists, the greater the rate of advance. Therefore, steps such as some that arise from the animal protection movement that would interfere with or reduce the amount of ongoing research must be resisted because the ultimate consequence would be the prolonging of avoidable human suffering.

In a crucial analysis of this belief, using physicists as a model, Cole and Cole (1972) studied the pattern of citation by physicists as a way of estimating who was responsible for advances. That is, who are the scientists that other scientists acknowledge as influencing their research? The research was extremely revealing and seemed to contradict the Ortega hypothesis. Specifically, the Coles found that a restricted 
number of physicists is responsible for the work that forms the base for future discoveries. They also concluded that even research projects that focused on topics of relatively minor significance relied to a great extent on the work of this elite group of scientists for direction and interpretation. More generally, and perhaps of even more importance, about half of all papers published in the 2,100 source journals abstracted in the Science Citation Index were found not to receive a single citation by another scientist in the year following publication, a period of time typically considered to be the peak period for citation. To the extent that citation analysis can be considered valid (see MacRoberts \& MacRoberts, 1987) and that these data apply to other disciplines, it raises interesting questions about just how many scientists are truly necessary for important advances to occur.

\section{Salami Science}

The notion of salami science (see Maddox, 1989) refers generally to the ways in which research is published by authors. Like salami, researchers must decide how to slice their work and make it available for consumption. A given research project may be published either in a series of small bites or fewer larger, dense slices. The former approach has the advantage of leaving an author with a greater number of individual publications (i.e., a thicker vita), whereas the latter presents a more cohesive and complete package that is available for immediate analysis and reaction. The basic tradeoff then is between appearance and communicative substance.

The essential criticism that follows from the notion of salami science is that research reports tend to become less useful as they become smaller and more specific in scope. As researchers increasingly slice their work thinly in order to respond to the primarily quantitative request to "publish or perish," publishers respond by creating journals of more and more limited content. Broad (1988) estimated in an article in the New York Times that approximately 40,000 scientific journals exist worldwide, with a minimum of 8,000 journals devoted to the publication of biomedical research. These journals publish approximately 1 million new articles a year. This deluge of material can actually be seen as an impediment to research and scientific progress. As work becomes more fragmented and narrow, the descriptive language also becomes more specialized and less understandable to those not directly in the area. These factors then interfere with attempts to determine the redundancy of a planned project and with attempts at summary and synthesis. Drummond Rennie (1989, p. 2545), senior editor at the prestigious Journal of the American Medical Association, put it this way:

There seems to be no study too fragmented, no hypothesis too trivial, no literature citation too biased or too egotistical, no design too warped, no methodology too bungled, no presentation of results too inaccurate, too obscure, and too contradictory, no analysis too self-serving, no argument too circular, no conclusions too trifling, or too unjustified, and no grammar and syntax too offensive for a paper to end up in print.

The implication is unmistakable: Any piece of research can be published somewhere if the author is persistent in his or her submission attempts. I have heard the following principle recounted many times by colleagues and, sadly, from my own lips: "Anything worth doing is worth publishing, and anything can be published somewhere." The maxim leads us to consider critically the fact that a percentage of research this trivial and fragmented is conducted on living flesh. It is one thing to waste our own time and the time of other scientists, but it is another thing to waste the lives of other animals for the sake of a longer vita or a thicker progress report. In a sense, the salami metaphor is inappropriate. When we slice salami thinly for the purpose of food consumption, it is done as a way to limit waste, to make sure that all the food is used to its most complete benefit. As we can see, the publication of research in tiny portions is the epitome of waste. The fact that the numbers game helps to drive research has always been a point of criticism, but the tradition is coming under increasing attention (e.g., Broad, 1981; Huth, 1986). On a more 
positive note, corrective proposals are beginning to emerge. For example, Angell (1986, p. 262) suggested that one strategy that would "affirm the supremacy of substance over volume" is to reduce or to place a ceiling on the number of publications that could be used to evaluate a researcher. The idea is to have the investigator select his or her best, say, five publications as part of an application. The expectation would be that this procedure would improve the quality of research and lead to an increase in the number of promotion and funding decisions made on the basis of evaluated excellence and that the unnecessary "fluff" in our huge scientific literature base would begin to be eliminated. I would add that, relevant to our current discussion, fewer animal subjects would be used, and when they were, the purpose of their use would be more adequately justified.

\section{Biased and Fraudulent Research}

As scientists, we are accustomed to the occasional revelation of fraud by a fellow researcher. The history of science is replete with what seems to be notable but rare examples of consciously planned and executed fabrications of experimental results. As undergraduates, we learned about the famous Piltdown Man; in the mid-1970s, we heard about Cyril Burt's missing identical twins and Summerlin's painted mice. The analysis of these frauds typically centered on a discussion of the individual's personality and work circumstance. We read about the pressured lives, the arrogance, and the status and money that accrued with research prominence (see McBride, 1974). The fraud issue was presented to be as rare as it was unseemly and a function of individual pathology. This position is still widely held.

In the late 1970 s to the 1980 s, a change in this pattern developed. During this period, there was an increase in the number of high-profile cases receiving public exposure, a broadening of concern to less dramatic cases now referred to as "intentional bias," and analyses that began to implicate the institution of science as a whole. St. James-Roberts $(1976 a, 1976 b)$ under the sponsorship of the British journal the New Scientist, began a study of cheating in science. The study was energized by fraud allegations directed at the highly regarded work on the genetics of IQ by Sir Cyril Burt. In this study, questionnaires were sent to the readership of the journal, asking respondents to indicate if they had encountered examples of intentional bias in their work. Of the 201 valid responses, $92 \%$ affirmed that they had some sort of direct or indirect (had heard about it) experience of acts of intentional bias. Sixty-six percent indicated that they had knowledge of more than one incident of intentional bias. Although this study cannot be considered definitive in any sense of the word, the implications are worth considering. The gist of the study is that it is possible that intentional bias is far more prevalent than we typically assume.

In April of 1988, John Dingell, Chairman of the Subcommittee on Oversight of the Committee on Energy and Commerce of the U.S. House of Representatives, held hearings focused on the topic of scientific fraud. His opening statement set the tone: "After our initial inquiry into this subject, we have reason to believe that we are only seeing [the cases of fraud that reach public attention] the tip of the iceberg." During those hearings, Drs. Walter Stewart and Ned Feder testified about their research into the John Darsee affair (see Stewart \& Feder, 1987). John Darsee was a promising and respected researcher in the area of clinical and experimental cardiology. He utilized both human subjects and dogs in his research. Over the period of 3 years, he published more than 100 articles while serving as a faculty member at Emory University and later Harvard University. In 1981, he pleaded guilty to one federal charge of data fabrication. Following that confession, it was determined that Darsee had in fact fabricated a substantial amount of the data that formed the basis of his publications. The focus of the investigation undertaken by Stewart and Feder was not Darsee but the professional practices of Darsee's co-authors. They reached the disturbing conclusion that about one third of the 47 co-authors were found to have engaged in significant departures from accepted practices of scientific research. Stewart and Feder's research, although eventually published, was held out of print for years due to repeated threats of litigation directed at possible publishers. Understandably, scientists wanted to protect their reputations. 
In an interesting and revealing twist on the need to protect reputations, John Maddox, editor of the journal Nature, was severely criticized for publishing an article widely believed to be an example of either intentional bias or extremely careless procedure (Maddox, 1988a, 1988b). Early in 1988, Nature ran an article by Jacques Benveniste and his associates, who purported to demonstrate the biological activity of extremely diluted solutions (Davenas et al., 1988). If true, the findings would have had monumental scientific consequences. When the article was published, it was followed by a reservation, which stated that the editor and reviewers had trouble believing the results and that the journal was sending its own independent investigative team to examine the laboratory practices of the authors. It was subsequently reported that the team had discovered basic errors in the conduct of the experiments that invalidated the results and conclusion. Maddox (1988a, 1988b) reported that he was angrily attacked by a number of scientists who charged him with irresponsible editorial behavior. Maddox (1988a, 1988b) defended himself by saying that he believed it was essential that scientists and the public alike recognize that second-rate science exists and should be exposed and eliminated. To conceal this fact and to pretend that all science was good and some especially so was the real act of irresponsibility. He asserted that not all scientists have a right to claim the respect and dignity deserved by the scientists who work in good faith (Maddox, 1988a, 1988b).

\section{AN ETHICAL CONSENSUS CANNOT BE REACHED}

\section{Good and Bad Animals}

There are strong indications that many researchers believe the current debates and regulatory requirements regarding animal treatment in biomedical research to be paradoxical and absurd. For example, Herzog (1988), in a brief but interesting article entitled "The Moral Status of Mice," illustrated how the labels we use to categorize animals and the roles we assign to them influence our sense of moral responsibility. In his article, he considered the case of the death of a child's pet mouse "Willie" and how the passing of the mouse was grieved and accorded a family funeral while at the same time the demise of kitchen mice ("pests") was planned and carried out dispassionately and without tears. It was pointed out that similar paradoxes exist in the laboratory and serve to confuse the issues.

Herzog elaborated further by suggesting that acceptable procedures utilized by a laboratory maintenance staff to rid the facility of feral and escaped mice would probably not be approved by Institutional Animal Care and Use Committees (IACUCs) if they were presented as part of a research protocol. Therefore, if the laboratory maintenance staff chose to clean the facility of the wild and "bad" mice by setting flypaper traps that attract and then hopelessly mire their quary in sticky cement until they suffocate, starve to death, or are in some other way disposed of, no one would complain. However, if an experimental procedure was proposed by a scientist that involved pasting rats to bread boards, it would surely be rejected as unacceptable and inhumane treatment.

Whereas Herzog presented the consequences of the "bad" and "good" distinction for discussion and invited analysis, Epling (1989) threw up his hands in frustration and perhaps disgust. More precisely, Epling lamented the fact that as an animal researcher he is legally required to justify and to ensure the careful treatment of animals that, if encountered outside the laboratory, are typically dealt with in the most expedient and brutal way. His representative illustration was made by comparing his "required" assurances and justifications to the behavior of the rat patrol of Alberta, Canada. Apparently, the rat patrol is responsible for maintaining the desired standard that this Canadian province remain rat free. In doing so, the patrol is apparently given carte blanche with respect to methods of extermination. Although he recognized that forcing researchers to formally justify the purpose of using animals in research helps to protect universities from bad publicity, he seemed to favor the conclusion that the process wastes time and, given the obvious social inconsistencies, is bizarre. Importantly, he went on to assure that he truly 
cares for rats and supports their use only in research with potential human benefit. It is as though he wished to crush this paradox by having the requirements to justify and to assure lifted from his list of responsibilities.

The point we wish to make is that the approach to the paradox exemplified here is problematical and contributes to the overall misunderstandings between animal activists and biomedical researchers. One important meaning of the term paradox is that it is an "apparent" contradiction resulting from a failure to look beneath the obvious. Unfortunately, like Epling and Herzog, we often are not motivated to resolve contradictions like these. First, as scientists, we seem to be at a loss to know what to do with ethics and values. We are generally reluctant to place them in the mind or in some other Platonic transcendant realm. Therefore, we tend to put them into behavior. This leads to a position of ethical relativism. This position espouses the view that because values, as recognized by behavior, differ among individuals, each belief is to some extent true. Moreover, if each differing value is true, there is no way of adjudicating among these differences (ethical skepticism). This can lead to the stand that all ethical decisions are ultimately arbitrary, culturally biased, and hence contradictory (Kitchener, 1980). Ethics, then, comes to be equated with the whims of politicians and the public. Ethical struggle becomes a struggle for the upperhand and, thus, a return to war. If the situation between animal activists and the biomedical community is to attempt to move toward consensus, we must be encouraged to search for a normative basis of animal ethics. We must avoid making the relativistic errors of assuming that what appears to be different is different and confusing what is with what ought to be.

As we have seen, a portion of the foundation of animal welfare regulation lies in the fact that many people have strong, authentic, and deep feelings for animals and that they express those concerns in the form of political action. Another source of this normative base, however, exists in the very reasons we state that we are studying animals in biomedical research. It is the assumption that such a study may or will teach us about the human condition. In other words, our work is based on the assumption of some form of continuity between humans and animals. Rollin (1986) showed clearly that researchers have often operated with a serious internal inconsistency. Although we have worked on the assumption of the existence of a physical continuity between humans and animals, we have ignored or rejected the notion of psychological continuity. That is, we have not always respected the position that there is reason to believe animals are sentient and are capable of experiencing pain and distress.

Therefore, when we as biomedical researchers are required to justify our research and to ensure concern for animal welfare, we are being asked to respect our belief in continuity. Because animals are sentient and experience pain-see the entire issue of the Journal of the American Veterinary Medical Association (Vol. 191, No. 10; see "Recognition and Alleviation of Animal Pain and Distress," 1987) for a thorough analysis of this position-and because what is done to them matters to them, the following questions must be asked: Do we have a good reason to do what we are doing? and How have we planned to reduce or to eliminate the animal's experience of distress? That the possibility exists that the members of the Alberta Rat Patrol care not a bit that rats are sentient does not invalidate the necessity for the justdiscussed ethical analysis. In fact, to assume that it does is confusing what is with what ought to be.

If Epling discovered that the patrol was devising ingenious yet sadistic ways to exterminate mice (e.g., frying them alive in large skillets), what is his duty? Should he call his political representative and argue that the Animal Welfare Act should be repealed? Or should he respond from a normative perspective that acknowledges that rats are sentient? The issue is the same for both Epling and the rat patrol. Whether an animal is being exterminated for health reasons or being tested in a biomedical experiment, the issues are the same. There must be a justifiable reason, and the methods should reflect and extend the hand of compassion. 


\section{SUMMARY}

1. The use of animals in research should evolve out of a strong sense of ethical self-examination. Ethical self-examination involves a careful self-analysis of one's own personal and scientific motives. Moreover, it requires a recognition of animal suffering and a satisfactory working through of that suffering in terms of one's ethical values. The lack of ethical self-examination is common and generally involves the denial or avoidance of animal suffering, resulting in the dehumanization of researchers and the ethical degradation of their research subjects.

2. The lack of ethical self-examination is being masked by an atmosphere of war that exists between animal activists and biomedical researchers. That is, both activists and researchers rely on SA as opposed to CA. In CA, participants ideally strive to reach a concensus through open and noncoercive discourse and behavior (see Donnelley \& Nolan, 1990, for an excellent example at an attempt to foster the discovery of concensus). By contrast, in SA, the goal of participants is not to deepen mutual understanding or to foster consensus among participants but, to the contrary, to strive for rhetorical and behavioral domination in either an overt or covert manner. SAs thus serve to undermine scientific discourse rather than protect and foster its development. The undermining of scientific discourse transforms science itself from an enterprise guided by informed ethical values to one guided by uninformed ethical values and, at worse, by motives of domination.

3. Three very important obstacles to communicative dialog that are perpetrated by the biomedical research community are: (a) lack of respect for the strong feelings about animals expressed by the animal protection movement; (b) a reluctance to admit to the existence of second-rate science due to fraud, misconduct, and mythmaking; and (c) a belief that differing sets of ethical values cannot be integrated or that a consensus cannot be reached between opposing parties.

\section{ACKNOWLEDGMENTS}

This article is based on a presentation given at a symposium on animal rights sponsored by the Department of Philosophy, University of Missouri, Columbia, April 25, 1990.

We gratefully acknowledge Charlene Mciver, Jerry Whorton, and Bernard Rollin for their crucial critiques of this article.

\section{REFERENCES}

Angell, M. (1986). Publish or perish: A proposal. Annals of Internal Medicine, 104, 261-262.

Beck, A. (1983). Animals in the city. In A. Katcher \& A. Beck (Eds.), New perspectives on our lives with companion animals (pp. 237-243). Philadelphia: University of Pennsylvania Press.

Becker, E. (1973). The denial of death. New York: Free Press.

Berman, M. (1989). Coming to our senses. New York: Simon \& Schuster.

Broad, W. J. (1981). Fraud and the structure of science. Science, 212, 137-141.

Broad, W. J. (1988, February 16). Science can't keep up with flood of new journals. New York Times, p. C20.

Campbell, J. (1983). The way of the animal powers: Historical atlas of world mythology. San Francisco: Harper \& Row.

Cole, J.R., \& Cole, S. (1972). The ortega hypothesis. Science, 178, 368-375.

Davenas, E., Beauvais, F., Amara, J., Oberbaum, M., Robinzon, B., Miadonna, A., Tedeschi, A., Pomeranz, B., Fortner, P., Belon, P., Sainte-Laudy, J., Poitevin, B., \& Benveniste, J. (1988). Human basophil degranulation triggered by very dilute antiserum against IgE. Nature, 333, 816-818. 
Dewsbury, D. (1990). Early interactions between animal psychologists and animal activists and the founding of the APA committee on precautions in animal experimentation. American Psychologist, 45, 315-327.

Dingell, J. (1988, April 12). Opening statement. Subcommittee on Oversight and Investigations, U.S. House of Representatives, Washington, DC.

Donnelley, S., \& Nolan, K. (Eds.). (1990, May/June). Animals science and ethics [Special supplement]. The Hastings Center Report.

Epling, W. (1989). Rats. The Behavior Analyst, 12, 251-253.

Feeney, D. (1987). Human rights and animal welfare. American Psychologist, 42, 593-599.

Habermas, J. (1984). The theory of communicative action (Vol. I). Boston: Beacon Hill Press.

Habermas, J. ( 1987). The theory of communicative action (Vol. 2). Boston: Beacon Hill Press.

Hallowell, A. (1926). Bear cerimonialism in the northern hemisphere. American Anthropologist, 28, 30.

Harris, J. (1983). A study of client grief responses to death or loss in a companion animal veterinary practice. In A. Katcher \& A. Beck (Eds.), New perspectives on our lives with companion animals (pp. 370-376). Philadelphia: University of Pennsylvania Press.

Herzog, H. (1988). The moral status of mice. American Psychologist, 43, 473-474.

Hittelman, K. (1989, May). Animal activists, federal policy, and institutional responsibilities. Animal care and use [Conference conducted at Texas A\&M University).

Huth, E. (1986). Guidelines on authorship of medical papers. Annals of Internal Medicine. 104, 269-274.

Katcher, A., \& Beck, A. (1983). New perspectives on our lives with companion animals. Philadelphia: University of Pennsylvania Press.

Kierkegaard, S. (1962). The present age (W. Lowrie, Trans.). New York: Harper \& Row.

Kitchener, R. F. (1980). Ethical relativism and behavior therapy. Journal of Consulting and Clinical Psyhology, 48, 1-7.

Lakolf, G., \& Johnson, M. (1980). Metaphors we live by. Chicago: University of Chicago Press.

Landers, S. (1989, April). Scientists take stand for animal research. APA Monitor, pp. 1-4.

Lawrence, E. (1982). Rodeo. Knoxville: University of Tennessee Press.

MacRoberts, M., \& MacRoberts, B. (1987). Citation counts. Nature, 327, 456.

Maddox, J. (1988a, September 26). A too-polite silence about shoddy science [Opinion]. New York Times.

Maddox, J. (1988b). When to publish pseudo-science. Nature, 334, 367.

Maddox, J. (1989). Is the salami sliced too thinly? Nature, 342, 733.

McBride, G. (1974). The Sloan-Kettering affair, could it have happened anywhere? Journal of the American Medical Association, 229, 1391-1410.

Midgely, M. (1893). Animals and why they matter. Harmondswoth, England: Penguin.

Mookerji, R. (1928). Asoka. London: Macmillan.

Recognition and alleviation of animal pain and distress. (1987). Journal of the American Veterinary Medical Association, 191(10).

Rennie, D. (1989). Editors and auditors. Journal of the American Medical Association, 261, 2543-2545.

Rollin, B. (1986). Animal consciousness and scientific change. New Ideas in Psychology, 4(2), 141-152.

Ruspoli, M. (1986). The cave of Lascaux. New York: Harry N. Abrahms.

Serpell, J. (1986). In the company of animals. New York: Basil Blackwell.

Stewart, W., \& Feder, N. (1987). The integrity of the scientific literature. Nature, 325, 207-214.

St. James-Roberts, I. (1976a). Are researchers trustworthy? New Scientist, 71, 481-483.

St. James-Roberts, I. (1976b). Cheating in science. New Scientist, 72, 466-469.

Trull, F. (1989, January 12). Family album [Memo]. National Association for Biomedical Research, Washington, DC.

Tuan, Y. F. (1984). Dominance and affection. New Haven: Yale University Press.

Tuan, Y. F. (1989). Morality and imagination. Madison: University of Wisconsin Press. 
Turnbull, C. (1962). The forest people: A study of the Pygmies of the Congo. New York: Simon \& Schuster.

Turnbull, C. (1963). The lesson of the Pygmies. Scientific American, 208, 1-11. 